\title{
Development and validation of a new method for the quantification of norfloxacin by HPLC-UV and its application to a comparative pharmacokinetic study in human volunteers
}

\author{
Danilo César Galindo Bedor ${ }^{1}$, Talita Mota Gonçalves ${ }^{1}$, Leila Leal Bastos' ${ }^{1}$, Carlos Eduardo Miranda \\ de Sousa', Luis Renato Pires de Abreu' ${ }^{1}$, Eduardo de Jesus Oliveira ${ }^{2}$, Davi Pereira de Santana ${ }^{1 *}$ \\ ${ }^{1}$ Núcleo de Desenvolvimento Farmacêutico e Cosmético, Universidade Federal de Pernambuco, NUDFAC/UFPE, \\ ${ }^{2}$ Laboratório de Tecnologia Farmacêutica, Universidade Federal da Paraíba
}

${ }^{*}$ Correspondence:

D. P. Santana

Núcleo de Desenvolvimento

Farmacêutico e Cosmético

Universidade Federal de Pernambuco

Rua Professor Arthur de Sá s/n

Cidade Universitária

50740-520 - Recife - PE, Brasil

E-mail: d-santana@bol.com.br
The development and validation of a simple and accurate method based on HPLC with ultraviolet detection for the quantification of norfloxacin (NFX) in human plasma and its application to a bioequivalence study between two norfloxacin formulations is described. NFX and the internal standard (cyprofloxacin) were extracted from plasma using liquid-liquid extraction. Chromatographic separation of norfloxacin, cyprofloxacin and plasma interferents was achieved with a C-18 column and a mobile phase consisting of $20 \mathrm{mM}$ sodium hydrogen phosphate buffer $\mathrm{pH} 3.0$ and acetonitrile $(88: 12, v / v)$ and quantitation was done at $280 \mathrm{~nm}$. The method was linear from 25 to $3000 \mathrm{ng} \mathrm{mL}^{-1}$ ( $\left.\mathrm{r}^{2} \geq 0.997578\right)$, and norfloxacin and cyprofloxacin had an average recovery from plasma of $93.9 \%$ and $91.2 \%$ respectively. The RSD of inter-day quality control samples at the lower limit of quantification was less than 15\%. After a single oral dose (400 mg) of norfloxacin administered to healthy human volunteers using a randomized $2 \times 2$ crossover design, pharmacokinetic parameters $\left(A U C_{0-p}, A U C_{0-\infty}\right.$ $C_{\text {max }}, t_{1 / 2}$ ) were derived from the plasma concentration curves for both formulations. Pharmacokinetic analysis of the data showed that the two formulations were bioequivalent, while no adverse reactions to the drug were observed.
Uniterms

- Norfloxacin

- HPLC

- Bioequivalence

- Pharmacokinetics

\section{INTRODUCTION}

Norfloxacin (1-ethyl-fluoro-1,4-dihydro-4-oxo-7(1piperazinly)-3-quinoline carboxylic acid) (Figure 1) is a large spectrum synthetic fluoroquinolone antibiotic which is structurally related to nalidixic acid (Córdoba-Borrego et al., 1999) (Figure 2). The addition of a fluorine atom at C-6 and a piperazine ring at C-7 has increased its potency in relation to other fluoroquinolones (Espinosa-Mansilla et al., 2006). Norfloxacin is synthesized by heating 1-ethyl6-fluor-7chloro-1,4-dihydro-4-oxoquinoline-3carboxylic 
acid (ECA) with piperazine (RAO 2004). Norfloxacin solutions are photosensitive to sunlight and to fluorescent light (Córdoba-Borrego et al., 1999).

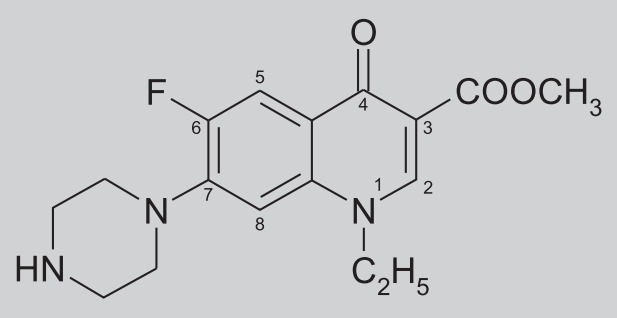

FIGURE 1 - Structural formula of norfloxacin.

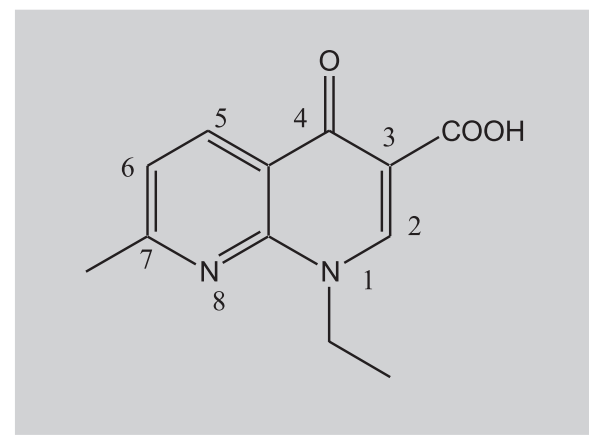

FIGURE 2 - Structural formula of nalidixic acid.

Norfloxacin is well tolerated and widely used against both gram-positive and gram-negative infections, including Neisseria gonorrhoeae, gentamycin-resistant Pseudomonas aeruginosa, Haemophilus influenzae, and methicillin-resistant Staphylococcus aureus (CórdobaBorrego et al., 1999; Rao, Nagaraju, 2004; Lim et al., 2002). It is mainly used in the treatment of urinary, respiratory and gastrointestinal tract infections (Rao, Nagaraju, 2004).

Norfloxacin is rapidly absorbed after oral administration (with 35 to $40 \%$ oral bioavailability). After an oral dose of $400 \mathrm{mg}$, plasma peak concentration (around $1,60 \mu \mathrm{g} / \mathrm{mL}$ ) is achieved within 3 hours. Plasma half-life is 5 hours (Farinotti, 1991). Approximately $30 \%$ of the administered dose is eliminated unaltered by the kidneys, producing high concentrations in urine (Vílchez et al., 2001). Indeed, norfloxacin is frequently used to treat urinary infections with a $400 \mathrm{mg}$ dose twice-daily regimen (Mascher, Kikuta, 1998).

High performance liquid chromatography methods have been used in the determination of norfloxacin in biological fluids and in pharmaceutical dosage forms (Carlucci, 1998). There are several methods in the literature for norfloxacin quantification in human plasma and in ani- mal tissues employing different extraction and detection strategies. Amongst those are liquid-liquid extraction with ultraviolet detection (Wallis et al., 1995), and protein precipitation with UV (Samanidou et al., 2003) or fluorescence detection (Well et al., 1998). More recent methods include liquid chromatography coupled to mass spectrometry detection (Toussaint et al., 2002; Ballesteros et al., 2003). Although these methods are suitable for the determination of norfloxacin in plasma, the limit of quantification of the UV-based methods is around $100 \mathrm{ng} \mathrm{mL}^{-1}$. While mass spectrometry provides a much higher sensitivity, the technique is not available to many laboratories. Thus, in order to accurately represent the elimination phase of the plasma-concentration-versus-time curve, we developed a simple and accurate method based on HPLC with UV detection and a lower limit of quantification of $25 \mathrm{ng} \mathrm{mL}^{-1}$.

The method was developed, validated and applied to the bioequivalence study of two $400 \mathrm{mg}$ tablets of norfloxacin. The study involved a single oral dose of $400 \mathrm{mg}$ of norfloxacin in an open, randomized, $2 \times 2$ crossover design using 26 healthy volunteers aged $18-45$ years (22.8 average) and a washout period of 7 days.

\section{MATERIAL AND METHODS}

\section{Chemicals}

Norfloxacin reference standard was acquired from the Instituto Nacional de Controle de Qualidade em Saúde (INCQS, Rio de Janeiro, Brazil) and cyprofloxacin (internal standard) from the United States Pharmacopea (Rockville, MD, EUA). HPLC-grade methanol and acetonitrile was purchased from J.T. Baker(Phillipsburg, NJ, EUA) and chloroform from Merck (Darmstadt, Germany). Sodium hydrogen phosphate and phosphoric acid were from Sigma-Aldrich (St. Louis, MO, EUA). Water was purified using a MilliQ ${ }^{\circledR}$ system from Millipore (Molsheim, France). Floxacin ${ }^{\circledR}$ (Merck Sharp \& Dhome) and the test formulation ( $400 \mathrm{mg}$ tablets) were purchased from the local pharmacy.

\section{Equipment}

High performance liquid chromatography was done using a chromatograph composed of two pumps (LC 10ADvp), a column oven (CTO 10Avp), a UV/VIS detector (SPD 10AVvp) configured to acquire data at $280 \mathrm{~nm}$, an autosampler ( SIL 10ADvp), and a system controller (SCL 10Avp) all from Shimadzu (Kyoto, Japão). For sample extraction a Jouan M23i refrigerated centrifuge (St. 
Herblaim, França) was used. Samples were stored at a $-70{ }^{\circ} \mathrm{C}$ REVCO (Ascheville, NC, EUA) freezer until analysis.

\section{Chromatography}

Chromatographic separation was achieved using a Gemini ${ }^{\circledR} \mathrm{C} 18$ column (Phenomenex, Torrance, CA, EUA) with $150 \times 4,6 \mathrm{~mm}$ and $5 \mu \mathrm{m}$ particle size coupled to a $\mathrm{C} 18$ 4,0 x 3,0 mm precolumn (also from Phenomenex). The mobile phase consisted of $20 \mathrm{mM}$ sodium hydrogen phosphate buffer (adjusted to $\mathrm{pH} 3.0$ with phosphoric acid) and acetonitrile $(88: 12, \mathrm{v} / \mathrm{v})$ which was filtered, degassed and pumped at a flow rate of $1.2 \mathrm{~mL} / \mathrm{min}$. The column oven was set at $40{ }^{\circ} \mathrm{C}$ and the injected volume was $50 \mu \mathrm{L}$. Quantitation of norfloxacin was done by measuring the response (area) of norfloxacin in relation to the response of cyprofloxacin (internal standard).

\section{Sample preparation}

\section{Preparation of working solutions and quality control standards}

The stock solutions of norfloxacin (at $1.0 \mathrm{mg} \mathrm{mL}^{-1}$ ) were prepared by dissolving the substance in methanol:water $(1: 1 \mathrm{v} / \mathrm{v})$ acidified with $30 \mu \mathrm{L}$ of formic acid and the internal standard stock solution (at $1.0 \mathrm{mg} \cdot \mathrm{mL}^{-1}$ ) was prepared in methanol:water $(1: 1 \mathrm{v} / \mathrm{v})$. The working solutions of norfloxacin were prepared in mobile phase (see chromatography above) to cover a range of concentrations from 25 to $3000 \mathrm{ng} \mathrm{mL}^{-1}$. The internal standard working solution was also prepared in mobile phase at a concentration of $4000 \mathrm{ng} \mathrm{mL}^{-1}$. The calibration curves for norfloxacin were prepared in human plasma at concentrations of 25, 50, 100, $300,600,1000,1500,2500$ e $3000 \mathrm{ng} \mathrm{mL}^{-1}$. Quality control samples were also prepared in human plasma at the following concentrations: 150, 1200 e $2250 \mathrm{ng} \mathrm{mL}^{-1}$ (low, medium and high quality controls respectively). All calibration samples were prepared by adding $100 \mu \mathrm{L}$ of norfloxacin stock solution to $9900 \mu \mathrm{L}$ of human plasma, taken from a pool of 6 volunteers. The concentration of norfloxacin stock solution used was adjusted to give upon dilution (10x dilution) the concentration required by the calibration sample to be prepared.

\section{Sample preparation}

Plasma samples $(250 \mu \mathrm{L})$ were transfered to a $2 \mathrm{~mL}$ polypropylene vial to which internal standard $(50 \mu \mathrm{L}$, $4000 \mathrm{ng} \mathrm{mL}^{-1}$ ) and $1 \mathrm{~mL}$ of chloroform was added. The samples were centrifuged at $10.000 \mathrm{rpm}$ for 1 minute. The vials were then frozen and the aqueous layer discarded. The organic phase was transferred to $2 \mathrm{~mL}$ glass vials and the solvent was evaporated to dryness at $40{ }^{\circ} \mathrm{C}$ under a stream of nitrogen. The residue was redissolved in $250 \mu \mathrm{L}$ of mobile phase, of which $200 \mu \mathrm{L}$ was transfered into $250 \mu \mathrm{L}$ glass vials and placed in the autosampler for analysis. The injection volume was $50 \mu \mathrm{L}$. Sample vials were wraped in aluminium foil to protect norfloxacin from light exposure.

\section{Clinical Protocol}

The bioequivalence study was conducted in 26 volunteers from 18 to 45 years (average of 22.8 years old), with an average weight of $69.26 \mathrm{~kg}$ (body mass index around $15 \%$ of ideal). The volunteers were submitted to an evaluation including anamnesis, psychological tests, electrocardiogram, and laboratory tests (hematological, serological and biochemical tests) four weeks before the beginning of the study. All volunteers were required to sign an informed consent form, and the clinical protocol had the approval of the Ethics Committee of Federal University of Pernambuco (Protocol number 066/2005). The volunteers were hospitalized in two occasions separated by a washout period of 7 days. At each period the volunteers (randomly assigned to the test or reference formulation) received in fasted state a single tablet of $400 \mathrm{mg}$ of norfloxacin administered with the aid of $240 \mathrm{~mL}$ of water. After 4 hours the volunteers received a standard meal. The 16 blood samples were collected by a heparinized butterfly at 0.0 , $0.5,1.0,1.25,1.5,1.75,2.0,2.5,3.0,4.0,6.0,8.0,10.0$, $14.0,18.0$ e 24.0 hours after dosing. At each time point, $8 \mathrm{~mL}$ of blood was withdrawn from the brachial vein and were transferred to glass containing EDTA. Blood samples were centrifuged at $2500 \mathrm{rpm}$ and plasma was stored in polypropylene cryogenic tubes at $-70^{\circ} \mathrm{C}$ until analysis.

\section{Validation}

\section{Selectivity}

Selectivity was evaluated by extracting plasma samples from a pool of plasma, including a lipemic and hemolysed plasma. The absence of interfering peaks at the same retention time of analytes or internal standard was considered as evidence for selectivity.

Linearity

Calibration curves were constructed using linear regression (with concentration as $1 / \mathrm{x}$ ) within the range of 25-3000 ng mL ${ }^{-1}$ of norfloxacin.

\section{Recovery}

Recovery of analyte was evaluated by comparing the response of norfloxacin in each quality control samples 
$\left(150,1200\right.$ e $\left.2250 \mathrm{ng} \mathrm{mL}^{-1}\right)$ with the response of norfloxacin in solutions prepared with the same nominal concentration. Recovery of internal standard was calculated in the same manner, but only at the working concentration (4000 $\mathrm{ng} \mathrm{mL}^{-1}$ ).

\section{Precision and accuracy}

For precision and accuracy studies, samples were prepared at 3 concentration levels (low, medium and high quality controls, corresponding to $150,1200 \mathrm{e} 2250 \mathrm{ng} \mathrm{mL}^{-1}$ respectively) with 5 replicates each, and were analysed in the same day (intra-day precision and accuracy), or prepared and analysed in 3 consecutive days (inter-day precision and accuracy).

\section{Stability studies}

The stability of the solutions and plasma samples was also evaluated during method validation. Norfloxacin stock solutions were analysed at two concentration levels (low and high quality control, corresponding to 150 and $2250 \mathrm{ng} \mathrm{mL}^{-1}$ respectively) both recently prepared or after 7 days stored at $4{ }^{\circ} \mathrm{C}$. The stability of norfloxacin was also evaluated in post-extracted samples kept in the autosampler at room temperature $\left(23^{\circ} \mathrm{C}\right)$ for 6 or 24 hours, as well as in plasma samples kept at $-70{ }^{\circ} \mathrm{C}$ for 62 days and after being submitted to 3 freeze-thawing cycles ( 24 hours each cycle). All samples described above were compared to freshly prepared norfloxacin samples at the same concentration level.

\section{Statistical anlysis, pharmacokinetics parameters}

Maximum plasma concentration $\left(\mathrm{C}_{\max }\right)$ and the time to reach it $\left(\mathrm{T}_{\max }\right)$ were derived directly from plasma concentration-versus-time curves. The area under the concentration-versus-time curve from $0-24 \mathrm{~h}\left(\mathrm{AUC}_{0-t}\right)$ was derived using the trapezoidal rule. The elimination constant $\left(K_{e}\right)$ was obtained using linear regression of the elimination phase data points and the plasma half-life $\left(t_{1 / 2}\right)$ was derived from the relation $t_{1 / 2}=\ln 2 \cdot K_{e}^{-1}$. The values of $\mathrm{C}_{\max }$ and $\mathrm{AUC}_{0-\mathrm{t}}$ were compared using parametric (ANOVA) and non-parametric (Wilcoxon) statistical analysis. Pharmacokinetics parameters and statistical analysis were calculated by noncompartmental pharmacokinetics modelling with the software WinNonlin ${ }^{\circledR}$, version 5.0.1.

\section{Adverse events}

The volunteers were evaluated through clinical observation and monitoring of vital signs such as arterial pressure, body temperature and pulse rate at baseline and at the end of each period volunteers were interviewed regarding the potential presence of adverse events (AEs) during the study.

\section{RESULTS AND DISCUSSION}

\section{Chromatographic optimization}

HPLC linked with photodiode array ultraviolet detector (DAD) has proven to be an important tool in the identification of compounds (Alabdalla, 2005). In our case the DAD was used for the selection of the best wavelength $(280 \mathrm{~nm})$ to maximize the signal of compounds and minimize the signal of plasma interferents. The chromatography conditions, especially the composition of mobile phase were optimized through several trials to achieve good resolution and symmetric peak shape for the analytes and I.S. The composition of the mobile phase was optimized by varying the percentage and $\mathrm{pH}$ of the sodium hydrogen phosphate buffer and percentages and type of organic component (Methanol or Acetonitrile). Finally $20 \mathrm{mM}$ sodium monobasic phosphate $\mathrm{pH} 3.0$ : acetonitrile $(88: 12, \mathrm{v} / \mathrm{v})$ was chosen as the final mobile phase since it provided the best separation, with higher sensitivity and selectivity for the UV signal of analytic and internal standard.

\section{Sample preparation}

The liquid liquid extraction procedure was developed by evaluating solvents of different polarity (diethyl ether, chloroform, ethyl acetate and dimethylsulfoxide), the ratio of sample to solvent volume and $\mathrm{pH}$. Except for chloroform, all the others solvents evaluated resulted in recovery rates lower than $60 \%$. The $\mathrm{pH}$ control of the extraction solution did not significantly interfered with the recovery of the analyte. Thus chloroform $(1.0 \mathrm{~mL})$ was chosen as the extraction solvent for sample preparation using $250 \mu \mathrm{L}$ of human plasma.

\section{Selectivity}

The described method used reversed-phase HPLC for separation of norfloxacin from cyprofloxacin (internal standard) and was shown to be selective for the analyte and its internal standard (retention times for norfloxacin and cyprofloxacin were 10.5 e 12.4 min respectively). No interfering peaks were observed with the same retention time of the analytes when plasma samples (including lipemic and hemolysed ones) from different volunteers were analysed (Figure 3). 

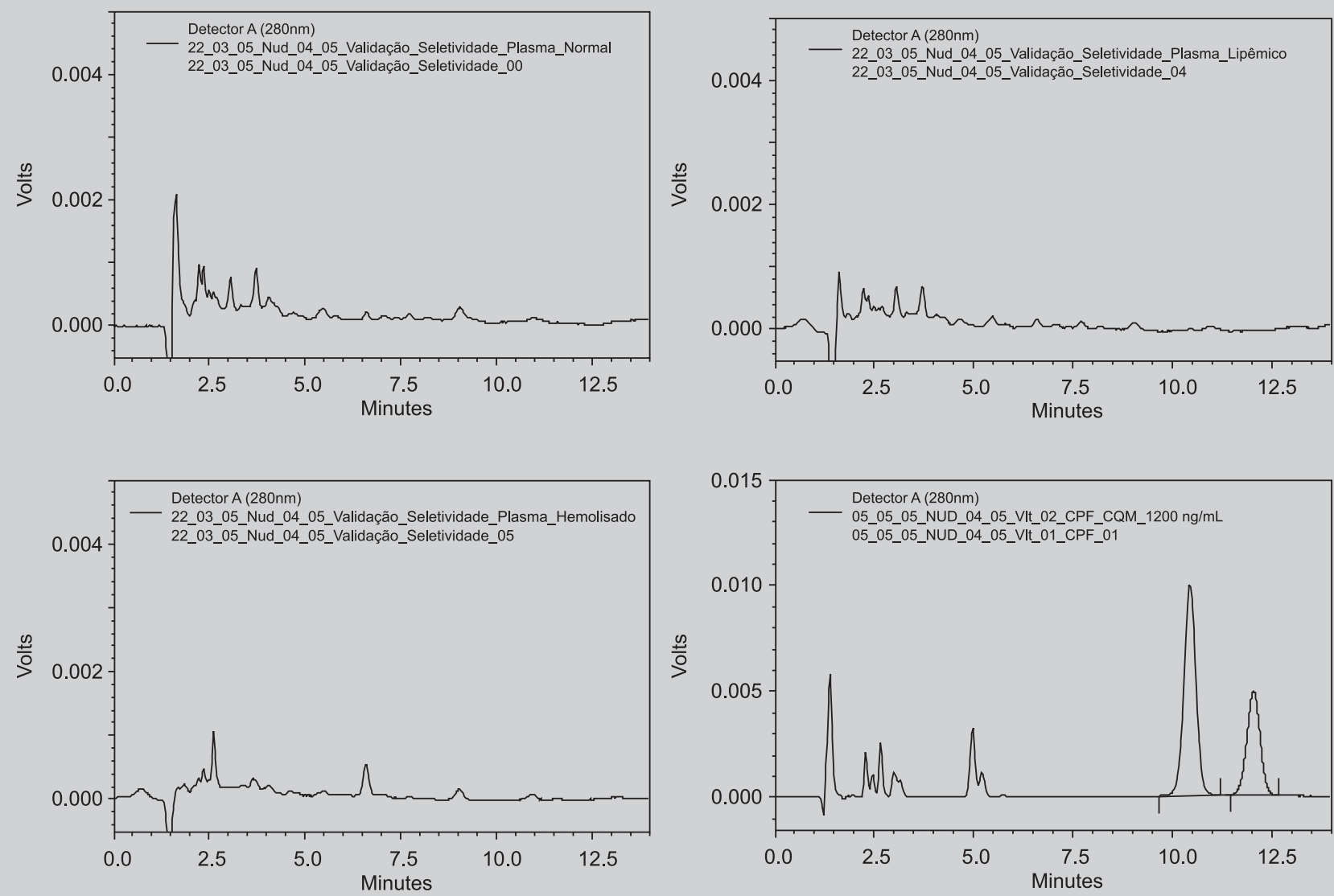

FIGURE 3 - Chromatograms demonstrating selectivity: A) normal plasma, B) Hemolysed plasma, C) Lipemic plasma and D) analyte (norfloxacin, $10.5 \mathrm{~min}$ ) at $1200 \mathrm{ng} \mathrm{mL}^{-1}$ and internal standard (ciprofloxacin, $12.4 \mathrm{~min}$ ) at $4000 \mathrm{ng} \mathrm{mL}^{-1}$.

\section{Linearity}

Linearity was demonstrated from $25-3000 \mathrm{ng} \mathrm{mL}^{-1}$. Table I show data from calibration curves prepared in different days throughout the application of the method.
Each point was analysed in triplicate. The average correlation coefficient was 0,9976 . The lower limit of quantification was determined to be $25 \mathrm{ng} \mathrm{mL}^{-1}$, which improved the accuracy of estimation of $\mathrm{AUC}_{0-\mathrm{t}}$ when compared to $\mathrm{AUC}_{0 \text {-inf }}$

TABLE I - The precision and accuracy of points of calibration curves

\begin{tabular}{lccc}
\hline $\begin{array}{l}\text { Nominal value } \\
(\mathrm{ng} \mathrm{mL})\end{array}$ & $\begin{array}{c}\text { Observed value }\left(\mathrm{ng} \mathrm{mL}^{-1}\right) \\
(\text { Average } \pm \mathrm{SD})(\mathrm{n}=13)\end{array}$ & $\begin{array}{c}\text { Precision } \\
(\%)\end{array}$ & $\begin{array}{c}\text { Accuracy } \\
(\%)\end{array}$ \\
\hline 25 & $25.17 \pm 0.83$ & 3.30 & 100.68 \\
50 & $49.73 \pm 0.33$ & 0.67 & 99.50 \\
100 & $99.16 \pm 1.31$ & 1.32 & 99.20 \\
300 & $319.09 \pm 22.83$ & 7.15 & 106.40 \\
600 & $600.99 \pm 2.13$ & 0.36 & 100.20 \\
1500 & $1536.29 \pm 61.42$ & 4.00 & 102.40 \\
2500 & $2427.58 \pm 23.36$ & 0.96 & 97.10 \\
3000 & $2887.63 \pm 73.63$ & 2.55 & 96.30 \\
\hline
\end{tabular}


The average recovery for norfloxacin in plasma was $82,34 \%, 93,97 \%, 97,25 \%(\mathrm{n}=15)$ for the low, medium and high quality control samples respectively $(150,1200 \mathrm{e}$ $2250 \mathrm{ng} \mathrm{mL}^{-1}$ ), with an average of $91,19 \%$. The average recovery of the internal standard was $93,91 \%$, evaluated at $4.0 \mu \mathrm{g} \cdot \mathrm{mL}^{-1}$.

\section{Precision and accuracy}

The intraday and interday precision and accuracy of the method for each norfloxacin concentration level (150, $1200 \mathrm{e} 2250 \mathrm{ng} \mathrm{mL}^{-1}$ ) and for the lower limit of quantification $\left(25 \mathrm{ng} \mathrm{mL}^{-1}\right)$ are presented in Table II. The relative standard deviation for the quality control samples and for the LLOQ were respectively $2.46,1.47,1.16$ e $10.6 \%$ and accuracy was $105.1,103.2,108.9$ and $108.6 \%$ respectively.

\section{Stability studies}

Norfloxacin stock solutions $\left(1 \mathrm{mg} \mathrm{mL}^{-1}\right)$ remained stable when stored at $4{ }^{\circ} \mathrm{C}$ for 7 days or when stored at room temperature up to 24 hours. When stored at $-70{ }^{\circ} \mathrm{C}$ for 62 days, spiked plasma samples of norfloxacin presented losses of 1.9 and $3.0 \%$ for concentrations of 150 and $2250 \mathrm{ng} \mathrm{mL}^{-1}$ respectively, in the others stability studies (stock solutions, post-extracted samples and 3 freezethawing cycles) norfloxacin did not show evidence of significant degradation.

\section{Pharmacokinetic parameters}

Figure 4 shows the averaged plasma concentrationversus-time curves for norfloxacin after administration of the reference (Floxacin ${ }^{\circledR}$ Merck Sharp \& Dhome, $400 \mathrm{mg}$ tablets) and test formulations. Table III shows the pharmacokinetic parameter values for the two brands (test and reference) of $400 \mathrm{mg}$ norfloxacin tablets.

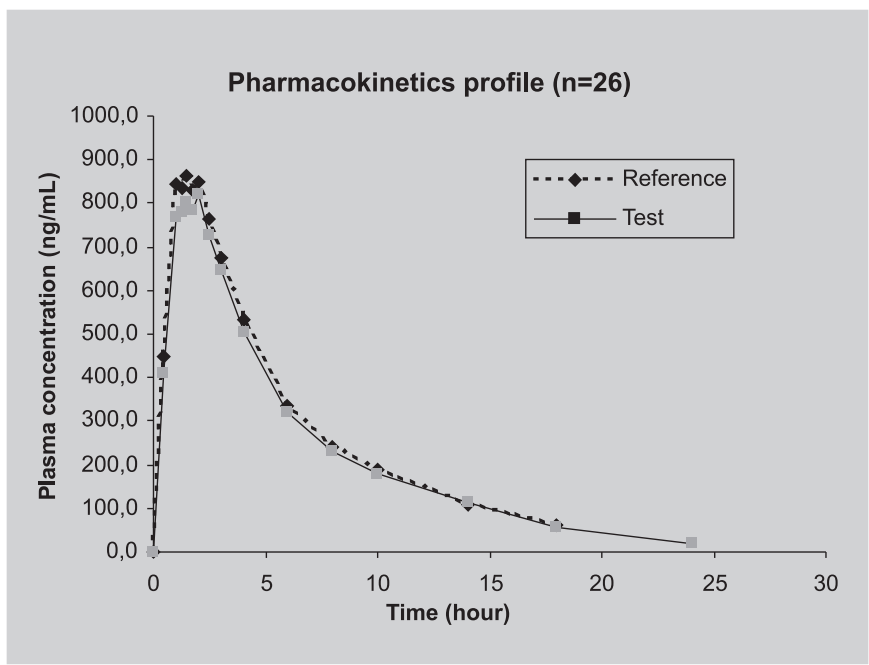

FIGURE 4 - The averaged plasma concentration-versustime curves for Norfloxacin after administration of the reference and test formulations.

TABLE II - Inter - and Intra-day precision and accuracy for norfloxacin

\begin{tabular}{|c|c|c|c|c|c|c|}
\hline \multirow{3}{*}{$\begin{array}{l}\text { Nominal value } \\
\left(\mathrm{ng} \mathrm{mL} \mathrm{L}^{-1}\right)\end{array}$} & \multicolumn{2}{|c|}{ Intra-day $\left(\mathrm{ng} \mathrm{mL} \mathrm{mL}^{-1}\right)(\mathrm{n}=5)$} & \multicolumn{4}{|c|}{ Inter-day $\left(\mathrm{ng} \mathrm{mL} \mathrm{m}^{-1}\right)(\mathrm{n}=15)$} \\
\hline & Day 1 & Day 2 & Day 3 & & & \\
\hline & Average \pm SD & Average \pm SD & Average \pm SD & Average \pm SD & Prec. & Acc. \\
\hline 25 & $27,191 \pm 1,16$ & $27,721 \pm 1,22$ & $26,311 \pm 1,02$ & $26,075 \pm 1,76$ & 6,75 & 104,3 \\
\hline 150 & $160,285 \pm 4,85$ & $157,615 \pm 5,96$ & $169,241 \pm 4,16$ & $162,380 \pm 6,95$ & 4,28 & 108,3 \\
\hline 1200 & $1238,441 \pm 18.25$ & $1286,710 \pm 66,90$ & $1340,121 \pm 32,28$ & $1288,424 \pm 59,32$ & 4,60 & 107,4 \\
\hline 2250 & $2451,103 \pm 50,89$ & $2449,544 \pm 69,39$ & $2537,510 \pm 29,50$ & $2479,386 \pm 73,85$ & 2,98 & 110,2 \\
\hline
\end{tabular}

TABLE III - Pharmacokinetic parameter for test and reference formulations

\begin{tabular}{lcc}
\hline Pharmacokinetic parameter & Test formulation mean $(\mathrm{RSD})$ & Reference formulation \\
\hline $\mathrm{AUC}_{(0-\mathrm{t})}(\mathrm{ng} / \mathrm{mL} . \mathrm{h})$ & $5532(31.7 \%)$ & $5285.79(32.7 \%)$ \\
$\mathrm{AUC}_{(0-\mathrm{inf})}(\mathrm{ng} / \mathrm{mL} . \mathrm{h})$ & $6029.12(29.3 \%)$ & $5961.32(29.6 \%)$ \\
$\mathrm{C}_{\max }(\mathrm{ng} / \mathrm{mL})$ & $1072.75(33.6 \%)$ & $1047.67(33.6 \%)$ \\
$\mathrm{T}_{\max }$ & $1.79(43.3 \%)$ & $1.61(49.5 \%)$ \\
$\mathrm{T} 1 / 2$ & $5.38(23.6 \%)$ & $6.40(42.4 \%)$ \\
$\mathrm{K}_{\mathrm{el}}(\mathrm{h} / \mathrm{h})$ & $0.14(27.3 \%)$ & $0.12(26.0 \%)$ \\
$\mathrm{Cl} / \mathrm{F}(\mathrm{L} / \mathrm{h})$ & $72.8(34.2 \%)$ & $74.3(36.8 \%)$ \\
\hline
\end{tabular}


The shortest confidence interval (90\%) for the ratio of $\mathrm{C}_{\max }$ means was $85.36 \%$ (lower limit) and $111.69 \%$ (upper limit). Mean $\mathrm{C}_{\max }$ calculated by method of least squares for the reference drug was 89.60 and 89.29 for the test, resulting in a ratio $\left(\mathrm{C}_{\max }\right.$ test/ $\mathrm{C}_{\max }$ reference $)$ of 97.64 and a test power of $86.50 \%$.

The area under the concentration-time curve from zero time to the time of the last sample collection, $\mathrm{AUC}_{(0-\mathrm{t})}$ had lower and upper shortest confidence limits $(90 \%)$ of 85.02 and 106.50 , respectively. The $\mathrm{AUC}_{(0-\mathrm{t})}$ means calculated by method of least squares were $123.425 \mathrm{ng} /$ $\mathrm{mL}$.h for the reference drug and $122.709 \mathrm{ng} / \mathrm{mL}$.h for the test drug resulting in a ratio (test/reference) of $95.15 \%$ and a test power for $\mathrm{AUC}_{(0-\mathrm{t})}$ of $94.69 \%$.

When the area under the concentration-time curve from zero to infinite $\left(\mathrm{AUC}_{0 \text {-inf }}\right)$ was calculated, the lower and upper shortest confidence limits (90\%) were 88.62 and 109.6 , respectively. The mean $\mathrm{AUC}_{(0 \text {-inf })}$ calculated for the reference and test formulation by the least squares were $137.182 \mathrm{ng} / \mathrm{mL} . \mathrm{h}$ and $136.950 \mathrm{ng} / \mathrm{mL}$.h resulting in a ratio (test formulation/reference formulation) of 98.55 and a power of test of $94.41 \%$.

\section{Adverse events}

No adverse effect was noticed during the period in which the volunteers were hospitalized and both formulations were well tolerated.

\section{CONCLUSION}

We described here the development of a new, selective, precise and accurate method for the quantification of norfloxacin in human plasma using HPLC with UV detection and liquid-liquid sample extraction which was applied to a bioequivalence study. Fluoroquinolones have been usually determined using fluorescence detection (Mascher, Kikuta, 1998; Well et al., 1998; Galaon et al., 2007). Although fluorescence detection is usually more sensitive than detection by UV, fluorescence detectors are not as widely available. Also, the limit of detection of a method is determined not only by detection technique but also by the effective clean-up of sample and minimization of band broadening by columns effects which can improve signal to noise ratio. The method reported here uses a simple and effective extraction technique with good and reproducible recovery and a limit of quantification of $25 \mathrm{ng} \mathrm{mL}^{-1}$. The developed method is suitable for pharmacokinetic studies of norfloxacin with a lower limit of quantification of $25 \mathrm{ng} \mathrm{mL}^{-1}$, which represents less than $2,5 \%$ of norfloxacin's $\mathrm{C}_{\max }$, and thus can be applied to estimation of pharmacokinetic parameters which are dependable of data points from the elimination phase such as $\mathrm{AUC}_{0 \text {-inf }}$. The method was applied to the analysis of more than 1200 samples with good accuracy and precision (less than 7\% RSD). The study was able to demonstrate bioequivalence (comparision of $\mathrm{AUC}_{\mathrm{o}-\mathrm{t}}$, $\mathrm{AUC}_{\text {o-inf. }}, \mathrm{C}_{\max }$ ) between the two formulations with a $90 \%$ confidence interval. Ahead of the clinical observations carried through during and after the study no adverse effect was observed, showing a good tolerability to the both formulations.

\section{ACKNOWLEDGEMENTS}

The authors wish to thank CNPq/CAPES and ANVISA-DF for financial support. Our gratitude for Iram Mundim for technical support.

\section{RESUMO}

\section{Desenvolvimento e validação de um método para quantificação de norfloxacino por cromatografia líquida de alta eficiência e aplicação a estudo de farmacocinética comparada em voluntários humanos}

O desenvolvimento e validação de um método simples e preciso por CLAE-UV para quantificação de norfloxacino (NFX) em plasma humano e a sua aplicação a um estudo de bioequivalência entre duas formulações são descritos. NFX e o padrão interno (ciprofloxacino, PI) foram extraidos do plasma através de extração líquido-líquido. A separação cromatográfica do NFX, do PI e dos interferentes do plasma foi realizada com uma coluna $C-18$ e fase móvel composta de tampão fosfato de sódio $20 \mathrm{mM}$ pH 3,0 e acetonitrila $(88 / 12, v / v)$ e quantificado em $280 \mathrm{~nm}$. A resposta do detector aos analitos mostrou-se linear entre 25 a $3000 \mathrm{ng} \mathrm{mL}^{-1}\left(r^{2} \geq 0,997578\right)$ e a recuperação média de NFX e PI foi de 93,9\% e 91,2\% respectivamente. O desvio padrão relativo de amostras analisadas ao nível do limite inferior de quantificação foi menor que 15\%. Foi administrada uma dose de NFX (400 mg) por via oral a voluntários humanos em um estudo aberto, aleatório e cruzado $2 \times 2$ entre duas formulações. Os parâmetros farmacocinéticos $\left(A U C_{0-p}, A U C_{0-\infty} C_{\text {max }}, T_{1 / 2}\right)$ foram observados a partir da curva de concentração versus tempo. A análise farmacocinética mostrou que as duas formulações são bioequivalentes entre si. Nenhum efeito adverso foi observado.

UNITERMS: Norfloxacino. CLAE. Bioequivalência. Farmacocinética. 


\section{REFERENCES}

ALABDALLA, M.A.. HPLC-DAD for analysis of diûerent classes of drugs in plasma. J. Clin. Forensic Med., v.12, p.310-315, 2005.

BALLESTEROS, O.; TORO, I.; SANZ-NEBOT, V.; NAVÁLON, A.; VÍLCHEZ, J.L.; BARBOSA, J.. Determination of fluoroquinolones in human urine by liquid chromatography coupled to pneumatically assisted electrospray ionization mass spectrometry. $J$. Chromatogr. B, v.798, n.1, p.137-144, 2003.

CARLUCCI, G.. Analysis of fluoroquinolones in biological fluids by high-performance liquid chromatography. $J$. Chromatogr. A, v.812,n.01-02, p. 343-367, 1998.

CÓRDOBA-BORREGO, M.; CÓRDOBA-DÍAZ, M.; CÓRDOBA-DÍAZ, D.. Validation of a high-performance liquid chromatographic method for the determination of norfloxacin and its application to stability studies (photostability study of norfloxacin). J. Pharm. Biomed. Anal., v.18, n.6, p.919-926, 1999.

ESPINOSA-MANSILLA, A.; DE LA PENA, A.M.; GÓMEZ, D. G.; LÓPEZ, F. S.. Determination of fluoroquinolonas in urine and serum by using high performance liquid chromatography and multiemission scan fluorimetric detection. Talanta, v. 68, n. 4, p.12151221, 2006.

FARINOTTI, R.; PEYTAVIN, G. Antibiotiques. In: LABAUNE, J.(Ed.). Propriétés pharmacocinétiques des medicaments. 1.ed. Paris: Masson, 1999. p. 144.

GALAON, T.; UDRESCU, S.; SORA, I.; DAVID, V.; MEDVEDOVICI, A. High-throughput liquidchromatography method with fluorescence detection for reciprocal determination of furosemide or norfloxacin in human plasma. Biomed. Chromatogr., v.21, n.1, p.40-47, 2007

LIM, J.; PARK, B.; YUN, H.. Sensitive liquid chromatographic - mass spectrometric assay for norfloxacin in poultry tissue. J. Chromatogr. B, n.772, n. 1 p.185-189, 2002.
MASCHER, H. J.; KIKUTA, C.. Determination of norfloxacin in human plasma and urine by highperformance liquid chromatography and fluorescence detection. J. Chromatogr. A, v.812, n.1-2, p.381-385, 1998.

RAO, R.N.; NAGARAJU, V.. Separation and determination of synthetic impurities of norfloxacin by reversed-phase high performance liquid chromatography. J. Pharm. Biomed. Anal., v.34, n.5, p.1049-1056, 2004.

SAMANIDOU, V.F,; DEMETRIOU, C.E.; PAPADOYANNIS, I.N.. Direct determination of four fluoroquinolones, enoxacin, norfloxacin, ofloxacin, and ciprofloxacin, in pharmaceuticals and blood serum by HPLC. Anal. Bioanal. Chem., v.375, n. 5, p.623-629, 2003.

TOUSSAINT, B.; BORDIN, G.; JANOSI, A.; RODRIGUEZ, A.R.. Validation of a liquid chromatography - tandem mass spectrometry method for the simultaneous quantification of 11 (fluoro)quinolona antibiotics in swine kidney. J. Chromatogr. A, v.976, n.12, p.195-206, 2002.

VÍLCHEZ, J.L.; BALLESTEROS, O. ; TAOUFIKI, J.; SÁNCHEZ-PALENCIA, G.; NAVALÓN, A.. Determination of the antibacterial norfloxacin in human urine and serum simples by solid-phase spectrofluorimetry. Anal. Chim. Acta, v.444, n. 2, p.279286, 2001

WALLIS, S.C.; CHARLES, B.G.; GAHAN L.R.. Rapid and economical high-performance liquid chromatographic method for the determination of norfloxacin in serum using a microparticulate $\mathrm{C}_{18}$ guard cartridge. J. Chromatogr. $B$, v.674, n.02,p.306-309, 1995.

WELL, M.; NABER, K.G.; KINZIG-SCHIPPERS, M.; SORGEL, F.. Urinary bactericidal activity and pharmacokinetics of enoxacin versus norfloxacin and ciprofloxacin in healthy volunteers after a single oral dose. Int. J. Antimicrob. Agents, v.10, n.1, p.31-38, 1998.

Recebido para publicação em 19 de dezembro de 2006. Aceito para publicação em 31 de maio de 2007. 